\title{
In Vivo Total Dose Analysis in Mice for BNCT Trial TRIGA Kartini Research Reactor Based Using PHITS
}

\author{
Ramadhan Valiant Gill S.B ${ }^{1}$, Surya Satrya Trihandaru ${ }^{2}$, Jodelin Muninggar ${ }^{3}$, Yohanes Sardjono ${ }^{4}$ \\ 1, 2, 3. Department of Physics, Faculty of Science and Mathematics, Satyawacana Christian University. \\ Email: ramadhan7valiant@gmail.com \\ ${ }^{4}$ PSTA-BATAN, Jln. Babarsari Kotak Pos 6010 ykbb, Yogyakarta 5528, Indonesia
}

\section{ARTICLE INFO}

Article history:

Received: 30 August 2018

Received in revised form: 30 October 2018

Accepted: 20 January 2019

\section{Keywords:}

Keyword PHITS

Keyword BNCT

Keyword In vivo

Keyword Total dose

Keyword Irradiation time

\begin{abstract}
A B S T R A C T
Boron neutron capture therapy (BNCT) is an effective radiotherapy modality to kill cancer. BNCT can selectively kill cancer cells without damaging the healthy tissue around it by using alpha particle and lithium ion from the reaction of $10 \mathrm{~B}(\mathrm{n}, \alpha) 7 \mathrm{Li}$. These particles have a track of more or less 5 to $9 \mu \mathrm{m}$ which is the same as the cell diameter. In order to support the development of BNCT in Indonesia an in vivo simulation is performed in a simple mouse geometry containing a 4T1 breast cancer characteristic treated with BNCT using PHITS program. The Neutron source that was used in this simulation was based on TRIGA Kartini Research Reactor. The boron compound concentration in the tumor was varied from $20 \mathrm{ppm}$ up to $90 \mathrm{ppm}$, and then the total dose was calculated in the mice. Total dose that the tumor received was $0.0161,0.0168,0.0175,0.0182,0.0185$, $0.0188,0.019$, and $0.0191 \mathrm{~Gy}-\mathrm{Eq} / \mathrm{s}$, respectively and the irradiation time to reach 50 Gy was $51,50,48,46,45,45,44,44,40$ minutes respectively. This shows that the higher the concentration of boron compound in the tumor the higher the dose that mice received and irradiation time was decreased with the increase of the boron compound concentration.
\end{abstract}

(C) 2019 IJPNA. All rights reserved.

\section{INTRODUCTION}

Boron Neutron Capture Therapy (BNCT) is one of the treatments that is developed throughout the world today including in Indonesia. There are many stages in the development of BNCT; one of which is trial on small animals (in vivo). Studies in small animals perform as an approach to human tests for a treatment. BNCT was applied in rats with colorectal liver metastasis using BPA as boron compound, this shows that after a 5-week follow-up there is no liver toxicity detected in the rats (Emilliano et al 2013). Another BNCT study was perform in a hamster with head and neck cancer, after a 16-week follow-up time no radiotoxicity was observed (Elisa M. Hebera 2014).

\footnotetext{
*E-mail: ramadhan7valiant@gmail.com
}

BNCT has a promising result in cancer treatment because it can selectively kill cancer cells without giving great damage to the healthy tissue around cancer by use of the alpha particle and ion lithium from the reaction of boron and thermal neutron $10 \mathrm{~B}(\mathrm{n}, \alpha) 7 \mathrm{Li}$ in the body and it is estimated that the particle track of the alpha and ion lithium is the same as cell diameter up to $9 \mu \mathrm{m}$ (Shinji Kawabata, M.D., et al 2013). Doses in the BNCT are very different and more complex from doses in other radiotherapy. BNCT has four components of doses which are doses from photon absorbed dose, fast neutron absorbed dose, nitrogen absorbed dose, and boron absorbed dose (Carl Ostlund 2005). There are 2 types of common boron compound that are used in BNCT which is BSH and BPA. Optimizing BNCT treatment can be done by 
improving the delivery of the boron carrier to the tumor (V. A. Trivillin., et al 2013). Selectivity of BNCT to cancer treatment is affected by ration of boron concentration in tumor and healthy tissue (Yoshiaki Yura, 2012).

In order to support a planning for experiments on BNCT, simulation was performed. Dosimetric efficacy of BNCT in liver metastases and liver cancer are investigated by simulation using MCNP and it shows that simulation using MCNP has potential (M. Blaickner, 2011). Another program used to simulate BNCT is PHITS, which can simulate a full-body phantom doses resulting from irradiation in BNCT treatment (Kenta Takada 2014) and also simulate an absorbed dose and neutron energy spectra resulting from accelerator (Monika Puchalska 2015).

In this study we simulated in vivo trial use PHITS program developed by Japan Atomic Energy Agency and calculated the total dose of each boron concentration that varies from 20 ppm up to $90 \mathrm{ppm}$. We used simple ellipsoid geometry as a mice body and a simple spherical geometry in the mice body as a tumor. The goal of this study is to support, provide data and reference for an experiment in the in vivo test in TRIGA Kartini Reactor. The Boron compound that was used in this study is BSH.

\section{MATERIALS AND METHODS}

\subsection{Neutron Source and in vivo test facility design}

This simulation used a neutron source based on characteristic thermal column TRIGA Kartini Research Reactor in Indonesia. We used a collimator design based on the previous study in simulation using MCNP to design a collimator for BNCT trial in thermal column TRIGA Kartini Reactor (M.Ilma Muslih Arrozaqi 2014). Neutron flux that came out from the aperture of the collimator in the simulation is $5.56 \times 10^{8}$. This result is still proper for BNCT trial. Small animals were put in a box as an in vivo facility with a volume 30 $\times 30 \times 30 \mathrm{~cm}^{3}$ that was made from $\mathrm{Al}$ (Figure.1).

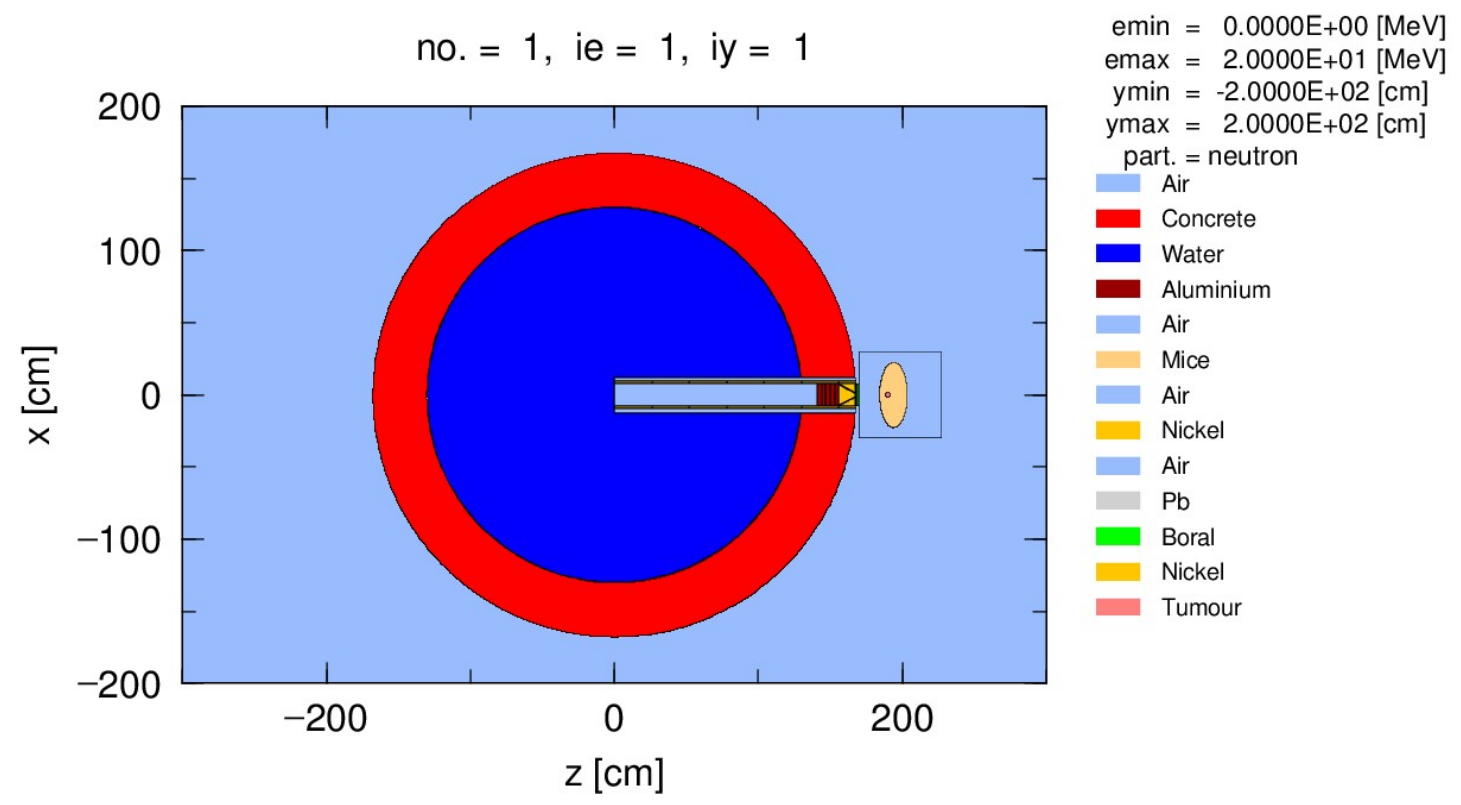

Fig. 1 Neutron source design which consists of collimator, moderator, filter, and in vivo facility based on TRIGA Kartini Research Reactor. Collimator design consists of $95 \%$ of nickel, $\mathrm{Al}$ as a filter, $\mathrm{Pb}$, and Boral. In front of collimator there is a box made from Al with a volume $30 \times 30 \times 30 \mathrm{~cm}^{3}$ filled with a mice.

\subsection{Animal Model}

We created simple ellipsoid geometry as a mice body consists with cancer in a form of a small spherical geometry inside the ellipsoid. We use $4 \mathrm{~T} 1$ breast cancer in this study, in 5 th week the tumor growth has reached a volume of $1000 \mathrm{~mm}^{3}$ (Bailey-Downs LC 2014). 
Component of the breast cancer is set up according to ICRU 44 (ICRU 1989). Figure 2 shows the geometry of the animal model.

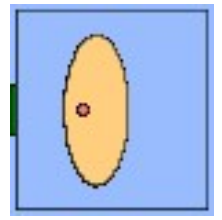

Fig. 2 Mice model with a $2 \mathrm{~cm}$ diameter $4 \mathrm{~T} 1$ tumor in a box made from $\mathrm{Al}$.

\subsection{Evaluating Total Dose in Mice}

Simulation using PHITS program (Particle and Heavy Ion Transport Code System) developed by Japan Atomic Energy Agency, we use two calculation mode; first based on tally [T-Deposit] in PHITS program, and second using kerma factor conversion as a multiplier in PHITS from flux to dose. The physical absorbed doses from the simulation convert to photon equivalent doses by multiplying each component of doses with the weighted factor (Minoru Suzuki 2014). In this simulation we vary the boron concentration in tumor which is 20 ppm, 30 ppm, 40 ppm, 50 ppm, 60 ppm, 70 ppm, $80 \mathrm{ppm}$, and $90 \mathrm{ppm}$. Volume of the tumor is the same for every boron concentration that is $1 \mathrm{~mm}^{3}$, and also mice and irradiation position is the same.

\section{RESULTS AND DISCUSSION}

Neutron flux distribution that came out in the aperture of the collimator by using PHITS program is $5.941 \times 10^{8}$ Figure. 3 this result is not very far from the previous study where neutron flux that came out in the aperture using MCNP simulation was $5.56 \times 10^{8}$ (Ilma Muslih Arrozaqi 2014). This result of neutron flux is still proper to use in the BNCT trial. In the previous study reactor criticality simulation with MCNP performed in order to get neutron output from the TRIGA Kartini reactor core, but in this PHITS simulation reactor criticality is not performed. We take the neutron spectrum output from the reactor core in MCNP simulation and use it as source input in our PHITS simulation.

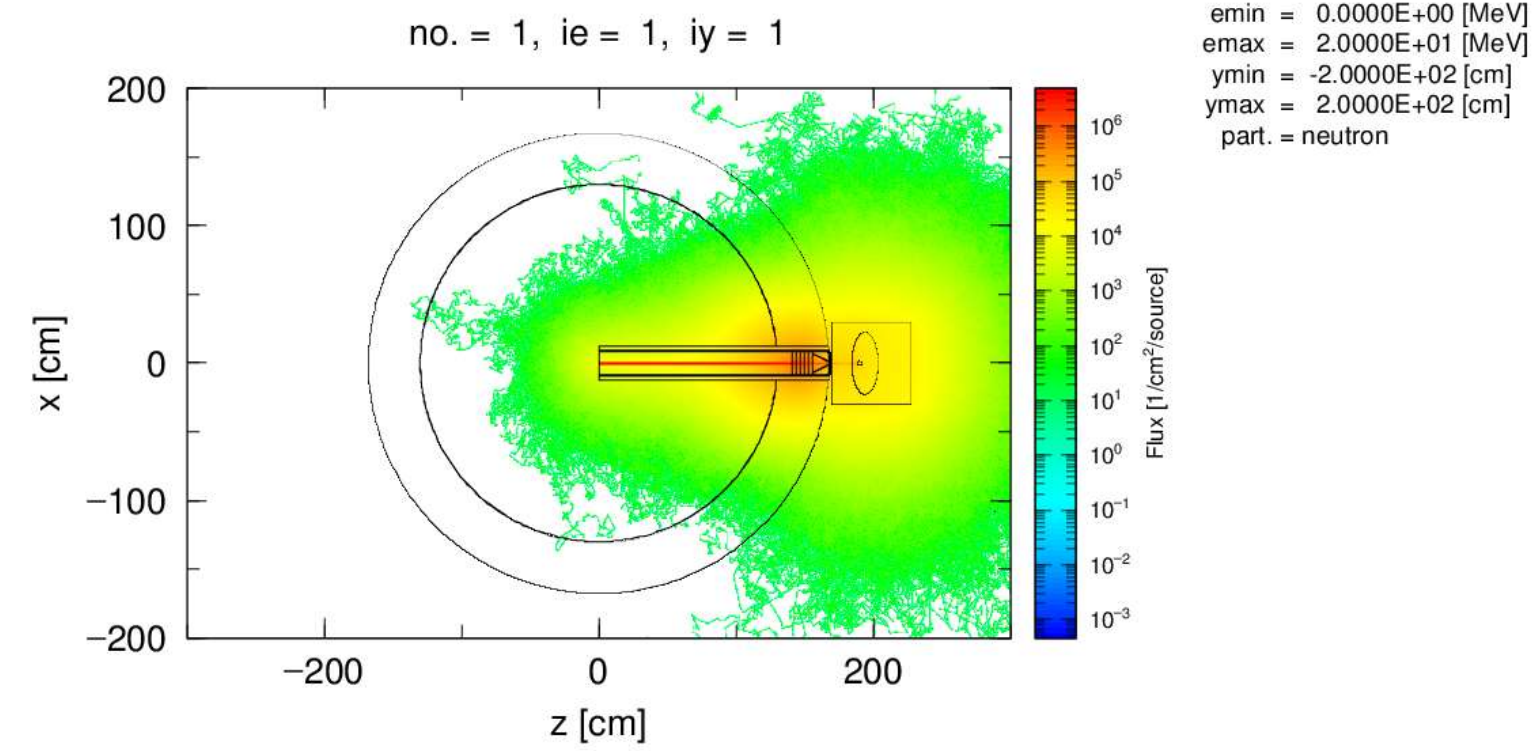

Fig. 3 Neutron flux distribution in the collimator, in vivo facility, and in the mice. Neutron flux that out from collimator is $5.55 \times 10^{8}$ and in the mice neutron flux is $1.2 \times 10^{7}$.

Table. 1 shows distribution of BNCT four component physical absorbed doses in mice. With the change of the boron concentration in the tumor boron absorbed doses increased, while the proton absorbed dose decreased. The neutron absorbed dose and the photon absorbed dose also change but only in a small fraction. Increasing of boron absorbed dose with the increasing of the boron concentration is due to the boron concentration in the tumor that 
increased. With this increased concentration the producing of alpha particle and lithium ion in the tumor becomes higher.

Table. 2 shows the total weighted dose that has been multiplied with the weighting factor of each component dose (Wolfgang 2012) in mice tumor. It also shows the irradiation time needed to reach dose 50 Gy-eq. With the increasing boron concentration in tumor the irradiation time becomes shorter. This is because high boron concentration produces more alpha and lithium ion. This result of irradiation times for in vivo simulation if compared to the previous study that using MCNP to simulate in vivo trial of BNCT (Adrian T. 2016) is more or less two times shorter. This is because in this simulation we did not define the GTV, CTV, and PTV and the mice geometry simpler than before.

Table. 1 Four component doses and total doses of bnct in mice.

\begin{tabular}{cccccc}
\hline \multirow{2}{*}{$\begin{array}{c}\text { Boron concentration in } \\
\text { tumor }(\mathrm{ppm})\end{array}$} & \multicolumn{5}{c}{ Dose (Gy/s) } \\
\cline { 2 - 6 } & Boron & ${ }^{14} \mathrm{~N}(\mathrm{n}, \mathrm{p})^{14} \mathrm{C}$ & Neutron & Photon & Total \\
\hline 20 & $6.09 \mathrm{E}-03$ & $1.01 \mathrm{E}-04$ & $1.60 \mathrm{E}-04$ & $1.34 \mathrm{E}-04$ & $6.49 \mathrm{E}-03$ \\
\hline 30 & $6.36 \mathrm{E}-03$ & $9.89 \mathrm{E}-05$ & $1.60 \mathrm{E}-04$ & $1.34 \mathrm{E}-04$ & $6.75 \mathrm{E}-03$ \\
\hline 40 & $6.64 \mathrm{E}-03$ & $9.74 \mathrm{E}-05$ & $1.59 \mathrm{E}-04$ & $1.34 \mathrm{E}-04$ & $7.03 \mathrm{E}-03$ \\
\hline 50 & $6.91 \mathrm{E}-03$ & $9.01 \mathrm{E}-05$ & $1.59 \mathrm{E}-04$ & $1.34 \mathrm{E}-04$ & $7.30 \mathrm{E}-03$ \\
\hline 60 & $7.07 \mathrm{E}-03$ & $8.49 \mathrm{E}-05$ & $1.59 \mathrm{E}-04$ & $1.34 \mathrm{E}-04$ & $7.44 \mathrm{E}-03$ \\
\hline 70 & $7.18 \mathrm{E}-03$ & $7.67 \mathrm{E}-05$ & $1.59 \mathrm{E}-04$ & $1.34 \mathrm{E}-04$ & $7.55 \mathrm{E}-03$ \\
\hline 80 & $7.25 \mathrm{E}-03$ & $8.02 \mathrm{E}-05$ & $1.59 \mathrm{E}-04$ & $1.34 \mathrm{E}-04$ & $7.62 \mathrm{E}-03$ \\
\hline 90 & $7.29 \mathrm{E}-03$ & $7.39 \mathrm{E}-05$ & $1.59 \mathrm{E}-04$ & $1.34 \mathrm{E}-04$ & $7.66 \mathrm{E}-03$ \\
\hline
\end{tabular}

Table. 2 Total weighted doses of each boron concentration and irradiation time.

\begin{tabular}{cccc}
\hline $\begin{array}{c}\text { Boron concentration in } \\
\text { tumor }(\mathrm{ppm})\end{array}$ & $\begin{array}{c}\text { Total dose weighted } \\
(\mathrm{Gy}-\mathrm{eq} / \mathrm{s})\end{array}$ & $\begin{array}{c}\text { Irradiation Time to } \\
\text { reach 50 Gy }(\mathrm{s})\end{array}$ & $\begin{array}{c}\text { Irradiation time to reach } \\
50 \text { Gy (minutes) }\end{array}$ \\
\hline 20 & $1.61 \mathrm{E}-02$ & $3.10 \mathrm{E}+03$ & $5.16 \mathrm{E}+01$ \\
\hline 30 & $1.68 \mathrm{E}-02$ & $2.98 \mathrm{E}+03$ & $4.96 \mathrm{E}+01$ \\
\hline 40 & $1.75 \mathrm{E}-02$ & $2.86 \mathrm{E}+03$ & $4.76 \mathrm{E}+01$ \\
\hline 50 & $1.82 \mathrm{E}-02$ & $2.75 \mathrm{E}+03$ & $4.59 \mathrm{E}+01$ \\
\hline 60 & $1.85 \mathrm{E}-02$ & $2.70 \mathrm{E}+03$ & $4.50 \mathrm{E}+01$ \\
\hline 70 & $1.88 \mathrm{E}-02$ & $2.66 \mathrm{E}+03$ & $4.44 \mathrm{E}+01$ \\
\hline 80 & $1.90 \mathrm{E}-02$ & $2.64 \mathrm{E}+03$ & $4.39 \mathrm{E}+01$ \\
\hline 90 & $1.91 \mathrm{E}-02$ & $2.62 \mathrm{E}+03$ & $4.37 \mathrm{E}+01$ \\
\hline
\end{tabular}




\section{CONCLUSION AND REMARKS}

We have studied the simulation of BNCT in vivo trial based on the TRIGA Kartini Research Reactor using PHITS. We evaluated the total dose and the irradiation time needed to reach 50 Gy-eq while we vary the boron concentration in mice tumor. We found that with the increasing of boron concentration in mice the total dose also increases and the irradiation time becomes shorter.

\section{ACKNOWLEDGMENT}

The authors wish to give a big thanks to Dr. Surya Satriya Trihandaru, Jodelin Muninggar, and Prof. Sardjono, and Made Adrian for guidance, criticism, and suggestion in writing this paper, and we also thank Dr. Susilo Widodo as a head of PSTA-BATAN who allowed us to do research in PSTA-BATAN.

\section{REFERENCES}

Adrian Tesalonika., Andang Widi Harto., Yohannes Sardjono., Isman Mulyadi Triatmoko., 2016. Dosimetry of in vitro and in vivo trials in thermal column Kartini Reactor for Boron Neutron Capture Therapy (BNCT) facility by using MCNPX simulator code. Indonesian Journal of Physics and Nuclear Applications., 1: 63-72.

Emiliano. C. C., Pozzi, Veronica A. Trivillin, et al. 2013, Boron neutron capture therapy (BNCT) for liver metastasis in an experimental model: dose-response at fiveweek follow-up based on retrospective dose assessment in individual rats., Radiat Environ Biophys., 52:481-491

Carl Ostlund et al., 2005. BNCT in vivo dosimetry: A feasibility study using an HPGe detector for prompt gamma spectroscopy, Med Rad Phy Clinical Sciences, Lund, Lund University. 4-5.

Elisa M. Hebera., M. Frederick Hawthorne., Peter J. Kueffer, Marcela A. Garabalino., Silvia I. Thorp., Emiliano C. C. Pozzi., Andrea Monti Hughes., Charles A. Maitz., Satish S. Jalisatgi., David W. Nigg., Paula Curotto., Verónica A. Trivillin., and Amanda E. Schwint., 2014. Therapeutic efficacy of boron neutron capture therapy mediated by boron-rich liposomes for oral cancer in the hamster cheek pouch model. PNAS., 111: 45.

H. Baba., Y. Onizuka., M. Nakao., M. Fukahori., T. Sato., Y. Sakurai., H. Tanaka., and S. Endo., Microdosimetric evaluation of the neutron field for BNCT at Kyoto University Reactor by using the PHITS code., Radiat Prot Dos. 143: 528-532.

ICRU, Tissue Substitutes in Radiation Dosimetry and Measurement, International Commission on Radiation Units and Measurements, Report44, Bethesda, MD (1989).

Kenta Takadaa., Tomonori Isobea., Hiroaki Kumadaa., Tetsuya Yamamotoa., Koichi Shidab., Daisuke Kobayashib., Yutaro Moria., Hideyuki Sakuraia and Takeji Sakae., 2014. Evaluation of the radiation dose for whole body in boron neutron capture therapy. Progress in Nuclear Science and Technology 4: 820-823.

Bailey-Downs LC, Thorpe JE, Disch BC, Bastian A, Hauser PJ, et al. (2014) Development and characterization of a preclinical model of breast cancer lung micrometastatic to macrometastatic progression. PLoS ONE 9(5): e98624.

M. Blaickner., J.V. Kratz., S. Minouchehr., G. Otto., H. Schmidberger., C. Schutz., L. Vogtlander., B. Wortmann., G. Hampel., 2011. Dosimetric feasibility study for an extracorporeal BNCT application on liver metastases at the TRIGA Mainz. Appl. Radiat. Isotopes. 70: 139-143.

M.Ilma Muslih Arrozaqi. (2014). Dasar-Dasar Pemrograman MCNPX. Yogyakarta: Pusat Sains dan Teknologi Akselerator Badan Tenaga Nuklir Nasional.

Minoru Suzuki., Ituro Kato., Teruhito Aihara, Junichi Hiratsuka, Kenichi Yoshimura, Miyuki Niimi, Yoshihiro Kimura., Yasunori Ariyoshi., Shin-ichi Haginomori., Yoshinori Sakurai., Yuko Kinashi., Shin-ichiro Masunaga., Masanori Fukushima., Koji Ono., and Akira Maruhashi., 2014. Boron neutron capture therapy outcomes for advanced or recurrent head and neck cancer. Journal of Rad Res, 55: 146-15.

Monika Puchalska and Lembit Sihver., 2015. PHITS simulations of absorbed dose out-offeld and neutron energy spectra for 
ELEKTA SL25 medical linear accelerator. Phys. Med. Biol. 60 N261-270.

Shinji Kawabata, M.D., Ph.D., Ryo Hiramatsu, M.D., Ph.D., Toshihiko Kuroiwa, M.D., Ph.D., Koji ono, M.D., Ph.D., 2013. Boron neutron capture therapy for recurrent highgrade meningiomas. J Neurosurg., 119: 837844.

V. A. Trivillin., M. A. Garabalino., L.L. Colombo., S.J. González., R.O. Farías ., A. Monti Hughes., E.C.C. Pozzi., S. Bortolussi ., S. Altieri ., M.E. Itoiz., R.F. Aromando., D.W. Nigg ., A.E. Schwint., 2013. Biodistribution of the boron carriers boronophenylalanine (BPA) and/or decahydrodecaborate (GB-10) for Boron Neutron Capture Therapy (BNCT) in an experimental model of lung metastases. Appl. Radiat. Isotopes.

Wolfgang A.G. Sauerwein., Andrea Wittig Raymond Moss., Yoshinobu Nakagawa., 2012. Neutron capture therapy principles and applications. Springer.

Yoshiaki Yura., Yusei Fujita., 2012. Boron neutron capture therapy as a novel modality of radiotherapy for oral cancer: Principle and antitumor effect. Oral Science International., 10: 9-14. 